\title{
7. NATURE OF FLUID INCLUSIONS IN SAMPLES OF THE DEEP SHEETED DIKES CORED DURING LEG 148 (HOLE 504B) ${ }^{1}$
}

\author{
Chifeng $\mathrm{Gu}^{2}$ and David A. Vanko ${ }^{2}$
}

\begin{abstract}
Hole 504B of the Ocean Drilling Program (ODP) provides the only available in situ samples of oceanic sheeted dikes. The rocks cored during Legs 137, 140, and 148 consist of altered diabase characterized by greenschist-facies secondary minerals. Fluid inclusions are abundant in plagioclase within highly altered vein halos, formed as apparently isolated inclusions or along healed planes of secondary inclusions. All fluid inclusions are two phase (liquid plus vapor) and liquid dominated (the volume of vapor is commonly less than $10 \%$ ).

Microthermometric results from plagioclase-hosted inclusions in the lower sheeted dikes reveal fluids with ice-melting temperatures ranging from $-0.1^{\circ}$ to $-4.9^{\circ} \mathrm{C}$. The corresponding fluid salinities range from 0.2 to $7.7 \mathrm{wt} \% \mathrm{NaCl}$ equivalent, similar to the salinities of fluids exiting submarine hydrothermal vents at mid-ocean ridges (about $0.4-7.0 \mathrm{wt} \% \mathrm{NaCl}$ equivalent). The mean salinities for individual samples are between 1.8 and $3.8 \mathrm{wt} \% \mathrm{NaCl}$ equivalent, close to that of seawater (3.2 wt\% $\mathrm{NaCl}$ equivalent). The fluid inclusions in some secondary planes display much lower salinities (less than $1.0 \mathrm{wt} \% \mathrm{NaCl}$ equivalent).

The measured homogenization temperatures of fluid inclusions range from $124^{\circ}$ to $211^{\circ} \mathrm{C}$. The mean homogenization temperatures for individual samples increase systematically with depth, from $135^{\circ} \mathrm{C}$ at $1500 \mathrm{mbsf}$ to $165^{\circ} \mathrm{C}$ at $2100 \mathrm{mbsf}$. This temperature range is much lower than that of hydrothermal alteration in the Hole $504 \mathrm{~B}$ dike complex $\left(250^{\circ}-350^{\circ} \mathrm{C}\right)$, that of predicted greenschist-facies alteration $\left(250^{\circ}-450^{\circ} \mathrm{C}\right)$, and that of fluids in modern black smoker vents $\left(250^{\circ}-400^{\circ} \mathrm{C}\right)$. Assuming a gas-free fluid, hydrostatic-pressure-corrected "trapping temperatures" for the sheeted dike section from Legs 111, 137, 140, and 148 range from $150^{\circ}$ to $201^{\circ} \mathrm{C}$, which is consistent with the present-day borehole temperatures. Lithostatic-pressurecorrected trapping temperatures are $15^{\circ}-25^{\circ} \mathrm{C}$ higher than the present-day borehole temperatures. Crushing experiments show that inclusions contain on the order of $0.1 \mathrm{~mol} \%$ compressible gas. If the presence of gas is considered, the lithostatic-pressurecorrected trapping temperatures correspond closely to the present borehole temperatures.

The sheeted dike complex at Hole 504B was altered at the ridge axis $5.9 \mathrm{~m} . \mathrm{y}$. ago at high temperature $\left(>350^{\circ} \mathrm{C}\right)$. The fluid inclusions, however, record temperatures appropriate for present-day conditions. Thus, fluid inclusions in hydrothermal plagioclase have been open systems, continually reequilibrating to the ambient conditions. Inclusions must be interpreted in terms of the history of temperature and pressure changes undergone by the young ocean crust as it formed at the mid-ocean-ridge axis and was then transported from the rift environment.
\end{abstract}

\section{INTRODUCTION}

Discoveries of hydrothermal venting at mid-ocean-ridge spreading centers and the recovery of hydrothermally altered rocks from the ocean ridges indicate that fluid circulation plays both a compositional and thermal role in crustal evolution (e.g., Kelley et al., 1993). Models of oceanic hydrothermal alteration are based largely on studies of ophiolites and samples of oceanic rocks. The ophiolite analogy provides a first-order picture of the lithostratigraphy of oceanic crust. Detailed investigations on the hydrothermal alteration of ophiolites have been conducted at numerous locations worldwide, particularly at the Troodos ophiolite in Cyprus (Richardson et al., 1987; Kelley and Robinson, 1990; Kelley et al., 1992), Semail ophiolite in Oman (Nehlig and Juteau, 1988; Pflumio, 1991; Regba et al., 1991), and Josephine ophiolite in California-Oregon (Harper et al., 1988; Alexander and Harper, 1994).

Research on oceanic hydrothermal systems encompasses fluid chemical studies of active hot springs (e.g., Von Damm et al., 1985; Von Damm and Bischoff, 1987), petrological and geochemical studies of ophiolites and altered oceanic crustal rocks (e.g., Stakes and Vanko, 1986; Vanko, 1988; Nehlig, 1991; Kelley et al., 1992, 1993,

'Alt, J.C., Kinoshita, H., Stokking, L.B., and Michael, P.J. (Eds.), 1996. Proc. ODP. Sci. Results, 148: College Station, TX (Ocean Drilling Program).

2Department of Geology, Georgia State University, Atlanta, GA 30303, U.S.A Gu: Chifeng_Gu@mail.dnr.state.ga.us; Vanko: geodav@gsusgil.gsu.edu
1995), and theoretical and experimental studies of seawater-rock interaction (e.g., Mottl, 1983; Seyfried et al., 1991). The present petrological investigation relates results of a fluid inclusion study of samples from the deepest oceanic samples recovered to date: diabase from the lower sheeted dike complex at Ocean Drilling Program (ODP) Hole 504B, Costa Rica Rift (Fig. 1). This study complements that of Kelley et al. (1995), who reported fluid inclusion data determined by our two laboratories for the Legs $137 / 140$ samples from Hole 504B. This paper extends coverage to the Leg 148 section.

Plagioclase-hosted fluid inclusions contain fluid with an average salinity near that of seawater, and with a range in salinity similar to that observed at modern, active hot springs. Homogenization temperatures of the inclusions, though, are much lower than the inferred temperatures at the time of trapping, and are coincident with the present-day borehole temperature. To explain these data, we propose a model, similar to and building upon that of Kelley et al. (1995), of fluid-trapping at high temperature, inclusion-underpressuring during crustal cooling, and open-system behavior of the inclusions.

\section{BACKGROUND}

Site 504 is located $200 \mathrm{~km}$ south of the Costa Rica Rift, the easternmost arm of the Galapagos Spreading Center in the eastern equatorial Pacific Ocean. This location is ideal for studying the effects of ridge flank hydrothermal alteration, as sediments accumulate rapidly and affect predictably the off-axis hydrothermal circulation (Becker et al., 1989). Hole 504B is dedicated to the study of crustal structure 


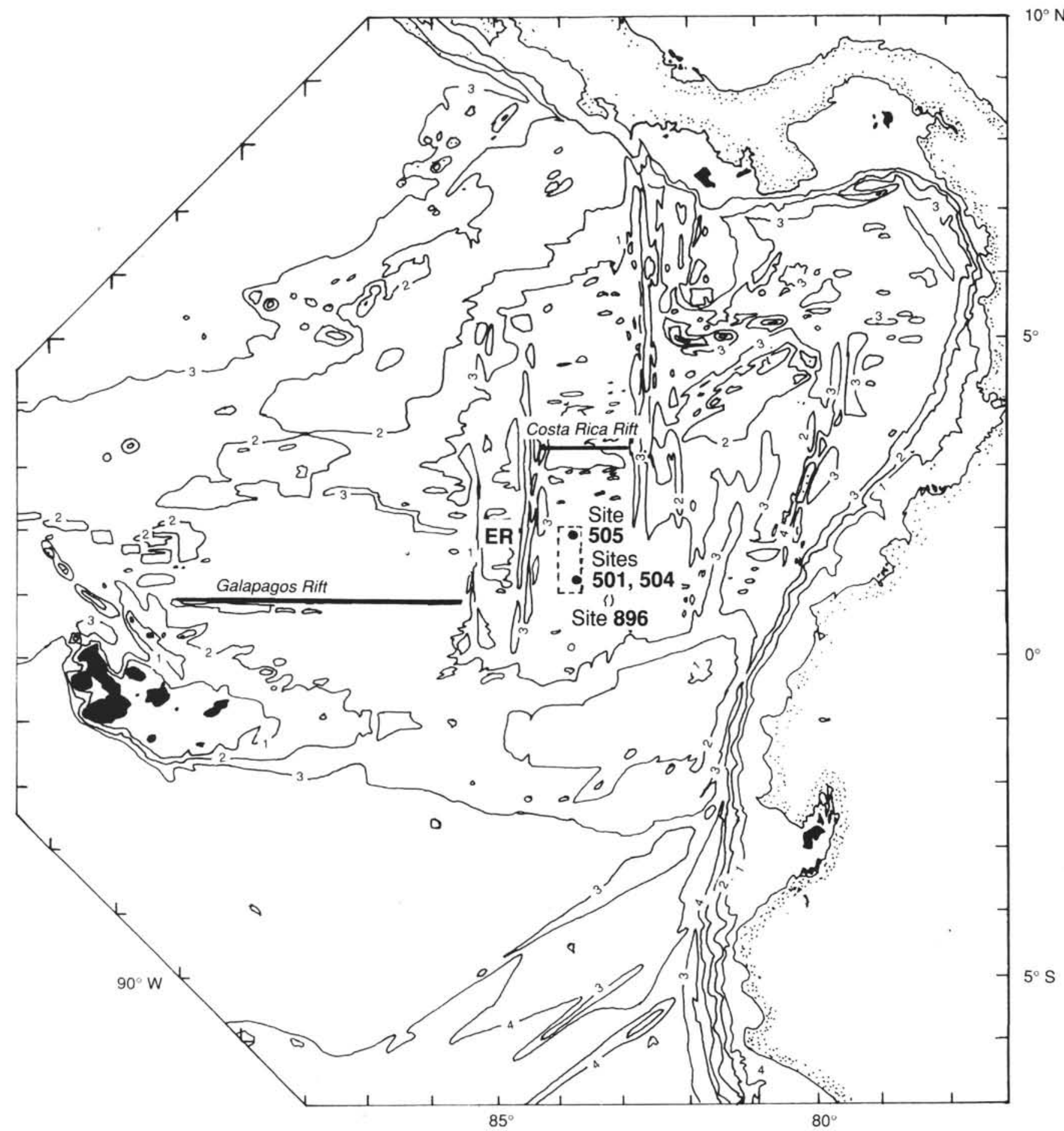

Figure 1. Location of DSDP Sites 501 and 505, DSDP/ODP Site 504, and ODP Site 896 south of the Costa Rica Rift in the eastern equatorial Pacific (after Hobart et al., 1985).

and hydrothermal processes in 5.9-m.y.-old oceanic basement. It is the deepest hole drilled for scientific purposes into the oceanic crust, and the only hole to penetrate through the volcanic section into the underlying sheeted dike complex, into seismic Layers 1, 2A, 2B, and 2C (Shipboard Scientific Party, 1992, 1993). Seven legs of the Deep Sea Drilling Project (DSDP; 69, 70, and 83) and ODP (111, 137, 140, and 148) contributed to the penetration $2111.0 \mathrm{~m}$ below seafloor (mbsf) in Hole 504B. Drilling has penetrated $274.5 \mathrm{~m}$ of sediments,
$571.5 \mathrm{~m}$ of pillow lavas and other volcanic rocks, $209 \mathrm{~m}$ of a transition zone of mixed pillows and dikes, and $1056 \mathrm{~m}$ of dikes and massive units that are interpreted to be the sheeted dike complex (Shipboard Scientific Party, 1993).

Hydrothermal alteration, characterized by minerals that are typical for greenschist-grade metamafic rocks, was first found at 898 mbsf in the transition zone, and $100 \%$ sheeted dikes began at 1055 mbsf. Petrological studies on samples collected from previous legs at 
Hole 504B are reported by Alt et al. (1985, 1989), Kawahata and Furuta (1985), Honnorez et al. (1985), Kawahata et al. (1987), Becker et al. (1989), and Schöps and Herzig (1990).

Through mineralogic and geochemical studies on the stockworklike samples (910-928 mbsf) from the pillow/dike transition zone, Honnorez et al. (1985) concluded that hydrothermal activity probably began close to the axis of the Costa Rica Rift. The analyzed fluid inclusions in that study were mainly in quartz with lesser amounts in analcime and calcite. The salinities are about $3.5 \mathrm{wt} \% \mathrm{NaCl}$ equivalent, matching that of seawater, and the average trapping temperatures of primary fluid inclusions in quartz range from $228^{\circ}$ to $338^{\circ} \mathrm{C}$ (Honnorez et al., 1985). A maximum alteration temperature of $380^{\circ} \mathrm{C}$ was calculated from oxygen isotope data on a quartz-epidote pair in a Leg 83 sample from about 1000 mbsf (Alt et al., 1985). These temperatures can only have resulted from hydrothermal activity driven by a magmatic heat source (Honnorez et al., 1985).

Microthermometric measurements of quartz-hosted fluid inclusions in the quartz-sulfide veins (1369-1388 mbsf) from the Leg 111 sheeted dike section (Schöps and Herzig, 1990) are characterized by relatively high salinities (4.2 to $7.2 \mathrm{wt} \% \mathrm{NaCl}$ equivalent). Fluid inclusion filling temperatures and oxygen isotope thermometry indicate fluid trapping temperatures from $350^{\circ}$ to $500^{\circ} \mathrm{C}$. The variations in the temperature and composition are interpreted to result from multiple stages of hydrothermal activity on-axis or near-axis (Schöps and Herzig, 1990).

Plagioclase-hosted fluid inclusions collected in the sheeted dike section (1370-1450 mbsf) cored during Leg 111 display mean salinities of 3.2 to $3.8 \mathrm{wt} \% \mathrm{NaCl}$ equivalent and uncorrected mean homogenization temperatures of $130^{\circ}$ to $140^{\circ} \mathrm{C}$ (Nehlig, 1991). A study of the mineralogy, chemistry, and stable isotopic compositions of the rocks recovered on Leg 111 has confirmed and extended the previous model for hydrothermal alteration at the site: axial greenschist-grade hydrothermal metamorphism was followed by seawater recharge and subsequent off-axis alteration, with temperatures during axial metamorphism of $250^{\circ}-350^{\circ} \mathrm{C}$ and water/rock ratios about 1 (Alt et al., 1989). We explain the discrepancy between metamorphic temperatures and the homogenization temperatures reported by Nehlig (1991) later in this paper.

Hole 504B was extended $378.9 \mathrm{~m}$ to a total depth of $2000.4 \mathrm{mbsf}$ during Legs 137 and 140 , and $110.6 \mathrm{~m}$ to a total depth of $2111.0 \mathrm{mbsf}$ during Leg 148. The recovery throughout the dike section in Hole 504B averages about 10\%-15\% (Shipboard Scientific Party, 1992. 1993).

The rocks of Legs 137, 140, and 148 are fine-grained massive diabase, predominantly magnesium-rich olivine tholeiites similar to moderately evolved mid-ocean-ridge basalts, but strongly depleted in incompatible trace elements. There appear to be no significant enrichment or depletion trends in chemical composition with depth, and there are no large-scale fractionation trends anywhere in this crustal section (Shipboard Scientific Party, 1992, 1993).

The circulation of seawater within the sheeted dike complex is marked by the formation of matrix and vein-filling greenschist mineral assemblages. Amphibole and secondary plagioclase formed by progressive metamorphism at temperatures of up to $400^{\circ} \mathrm{C}$ or higher (Laverne et al., 1995; Vanko et al., this volume), and quartz and epidote and other greenschist minerals formed in veins during axial hydrothermal alteration at temperatures of $250^{\circ}-380^{\circ} \mathrm{C}$. Later, as the crust moved off-axis into a recharge zone, penetration of seawater into still-warm rocks resulted in precipitation of anhydrite in cracks and local replacement of plagioclase by anhydrite. Zeolites formed in fractures and rocks during later off-axis alteration at lower temperature.

Below 1500 mbsf, secondary calcic plagioclase with compositions ranging from anorthite to labradorite partially replaces magmatic plagioclase (Shipboard Scientific Party, 1993; Laverne et al., 1995; Vanko et al., this volume). These secondary calcic plagioclase rims contain abundant fluid inclusions (Kelley et al., 1995), and have provided most of the data for the present study.

Water-rock interactions of highly variable intensity occurred throughout the dikes and at various times after their emplacement and crystallization. As a consequence, nearly all of the recovered rocks from the sheeted dike section exhibit some hydrothermal alteration to greenschist facies mineral assemblages, with a pervasive slight "background" alteration and locally more extensively altered zones around veins and in centimeter-sized patches (Becker et al., 1989; Shipboard Scientific Party, 1992, 1993; Laverne et al., 1995). The types of veins and their relative abundance remain nearly the same in samples recovered during Legs 137, 140, and 148 (Shipboard Scientific Party, 1993).

\section{METHODS}

Forty rock samples were obtained for this study by sampling cores from Hole 504B during Legs 137, 140, and 148. Samples represent the major lithology (diabase) and its altered equivalents: veined diabase, alteration halos around veins, alteration patches, and rare latestage quartz veins. Fluid inclusions were analyzed from 22 samples, of which 16 are vein halos, one is a quartz vein, and the rest are alteration patches or representative of the background rock alteration.

\section{Microthermometric Data Collection}

Microthermometric analyses were conducted following the procedures of Roedder (1984) to determine the ice-melting temperatures $\left[\mathrm{Tm}\right.$ (ice), $\left.{ }^{\circ} \mathrm{C}\right]$ and homogenization temperatures $\left(\mathrm{Th},{ }^{\circ} \mathrm{C}\right.$ ) using a gasflow heating/freezing stage manufactured by Fluid Inc. Freezing and heating measurements were made on individual inclusions in order to obtain corresponding homogenization temperatures and ice-melting temperatures (fluid salinities); however, for a few inclusions either Tm(ice) or Th could not be measured, as it either was too small for observing the ice-melting phase change or had decrepitated before the homogenization phase change could be observed. All freezing data were collected before heating to avoid decrepitation. Homogenization temperatures were measured during progressive heating of the sample in order to avoid decrepitation and potential modification of phase-change temperatures owing to stretching and leaking.

Calibration was done periodically using synthetic fluid inclusions that have known phase transitions at $-56.6^{\circ}, 0.0^{\circ}$, and $+374^{\circ} \mathrm{C}$. The error of a measured temperature is estimated to be $\pm 0.5^{\circ} \mathrm{C}$ during heating and $\pm 0.1^{\circ} \mathrm{C}$ during freezing.

\section{Crushing Experiments}

The behavior of fluid inclusions when they are opened to the atmosphere provides information on the presence of gas and internal gas pressures (Roedder, 1970). Several large (>15 $\mu \mathrm{m})$ inclusions were crushed. Small chips were placed in oil between two glass slides in a crushing device on the microscope stage. Individual inclusions were observed to determine whether vapor bubbles collapsed or expanded when the inclusions were broken.

\section{RESULTS General Description}

Fluid inclusions are common to rare in plagioclase and are rare in quartz. Inclusions are most abundant within the highly altered halos of veins and vugs, particularly in secondary calcic plagioclase. This suggests that the formation of most inclusions is related to the alteration event responsible for forming the veins and vugs. A few sam- 


\section{Crushing Results}
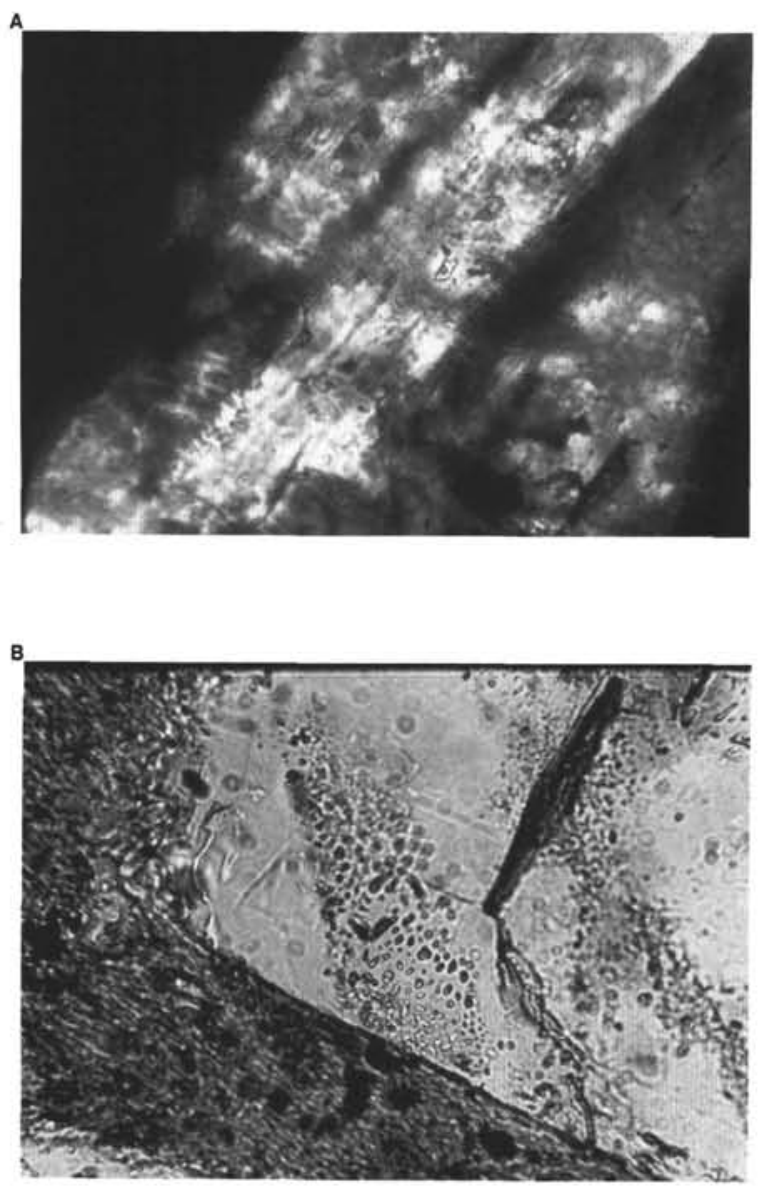

Figure 2. Photomicrographs of fluid inclusions. Each photograph is $375 \mu \mathrm{m}$ wide. A. Primary(?) isolated, individual liquid-dominated inclusion, Sample 148-504B-247R-I (Piece 10, 36-43 cm). B. Inclusions in secondary planes, Sample 148-504B-247R-1 (Piece 10,36-43 cm).

ples contain rare fluid inclusions in vein quartz (for example, Sample 140-504B-216R-1, Piece 13, 58-69 cm).

Inclusions occur as isolated individuals (Fig. 2A) or along healed fractures (Fig. 2B) and vary from angular to irregular in shape. Most of the inclusions studied have maximum dimensions ranging from 10 to $20 \mu \mathrm{m}$, although a few as large as $70-100 \mu \mathrm{m}$ were observed.

Both primary and secondary fluid inclusions may be present. Those that form arrays along healed microfractures are interpreted to be secondary (for example, there are numerous secondary inclusion planes in Sample 148-504B-247R-1, Piece 10, 36-43 cm; see Fig. $2 B$ ). In most grains it is impossible to determine unambiguously the inclusion origin. However, because inclusions are restricted primarily to vein and vug halos, and are further commonly restricted to the secondary plagioclase within these halos, their original formation is thought to be related to the original vein- and vug-filling event. Subsequent modification of the inclusions may have occurred, as will be discussed later.

All the inclusions studied consist of two phases-liquid and vapor without daughter crystals at room temperature (see Fig. 2A). They are liquid dominated, with the vapor phase typically comprising $5 \%$ to $10 \%$ by volume.
Upon crushing, three chips from Samples 148-504B-247R-1 (Piece 10, 36-43 cm) and 148-504B-249R-1 (Piece 7B, 21-24 cm) yielded interpretable observations. Each inclusion had initially about $10 \%$ vapor. As each inclusion broke, it became completely filled by vapor. If we assume the presence of an ideal gas, the roughly 10 -fold volume increase in vapor suggests that the initial partial pressure of the gas was about $10 \mathrm{~atm}$, and the inclusion contained about 0.1 mol\% gas, probably $\mathrm{CH}_{4}$ or $\mathrm{CO}_{2}$ (e.g., Kelley et al., 1995).

\section{Freezing Results}

Ice melting temperatures of fluid inclusions vary from $-0.1^{\circ}$ to $-4.9^{\circ} \mathrm{C}$, corresponding to 0.2 to $7.7( \pm 0.2) \mathrm{wt} \% \mathrm{NaCl}$ equivalent (using the equation of Bodnar, 1993) (Table 1; Figs. 3-5). The mean salinities vary from 1.8 to $3.8 \mathrm{wt} \% \mathrm{NaCl}$ equivalent. Samples 148 504B-247R-1 (Piece 10, 36-43 cm) and 148-504B-248R-1 (Piece 7B, 21-24 cm) exhibit the lowest mean salinities (1.9 and $1.8 \mathrm{wt} \%$ $\mathrm{NaCl}$ equivalent, respectively), which can be attributed to the many fluid inclusions measured in these two samples that are in secondary planes and that display uniformly lower salinities (mostly $0.2-1.5$ $w t \% ~ \mathrm{NaCl}$ equivalent, Fig. 4). There is no apparent systematic change in salinity with depth throughout the $\sim 500 \mathrm{~m}$ of sheeted dikes penetrated during Legs 137, 140, and 148 (Fig. 5).

\section{Heating Results}

Uncorrected homogenization temperatures of fluid inclusions recovered from Hole 504B during Legs 137, 140, and 148 vary from $127^{\circ}$ to $211^{\circ} \mathrm{C}$ (Fig. 6), with most falling between $140^{\circ}$ and $170^{\circ} \mathrm{C}$. Mean homogenization temperature increases significantly with depth (at about $60^{\circ} \mathrm{C} / \mathrm{km}$, with a correlation coefficient of 0.93 ) (Fig. 7).

Vapor bubbles result from shrinkage of the liquid as the temperature decreases from the temperature of trapping to the temperature of observation (Roedder, 1984). For inclusions that originally trapped a single, homogeneous fluid phase, homogenization temperatures are lower than the trapping temperatures. The difference between the trapping temperature and homogenization temperature is a function of the entrapment pressure and of fluid composition. We determined trapping temperatures for each sample by taking the mean homogenization temperature and, with the equations of Zhang and Frantz (1987), calculating pressure corrections assuming that entrapment pressures were somewhere between a cold hydrostatic gradient (100 bars/1000 $\mathrm{m}$ for the sample recovery depth plus an overlying water column of $3460 \mathrm{~m}$ ) or a lithostatic gradient ( 100 bars $/ 1000 \mathrm{~m} \mathrm{H}_{2} \mathrm{O}$ for an overlying water column of $3460 \mathrm{~m}$, plus 294 bars $/ 1000 \mathrm{~m}$ oceanic rocks for the sample recovery depth). The fluid was assumed initially to be gas-free $\mathrm{NaCl}-\mathrm{H}_{2} \mathrm{O}$ solution.

Combining data from the sheeted dikes from Leg 111 (Nehlig, 1991) and Legs 137, 140, and 148 (this study and Kelley et al., 1995), the mean homogenization temperatures, as well as the trapping temperatures, increase with depth (Fig. 8). Uncorrected homogenization temperatures increase from $139^{\circ}$ to $168^{\circ} \mathrm{C}$, and corresponding trapping temperatures increase from $165^{\circ}$ to $205^{\circ} \mathrm{C}$ for the cold hydrostatic-pressure correction, or from $180^{\circ}$ to $223^{\circ} \mathrm{C}$ for the lithostaticpressure correction (Table 1; Fig. 8).

\section{DISCUSSION}

\section{Fluid Salinity}

Seawater has a salinity of $3.2 \mathrm{wt} \% \mathrm{NaCl}$ equivalent (Bischoff and Rosenbauer, 1985). The salinities of the diabase-hosted fluid inclusions from Legs 137,140 , and 148 are $0.2-7.7 \mathrm{wt} \% \mathrm{NaCl}$ equivalent (from $60 \%$ below to $240 \%$ above seawater concentration). The salinity range is similar to that of fluids exiting active submarine hydro- 
Table 1. Microthermometric data from Hole 504B fluid inclusions.

\begin{tabular}{|c|c|c|c|c|c|}
\hline $\begin{array}{l}\text { Core, section, } \\
\text { piece number }\end{array}$ & $\begin{array}{l}\text { Depth } \\
\text { (mbsf) }\end{array}$ & $\begin{array}{c}\text { No. of } \\
\text { inclusions }\end{array}$ & $\begin{array}{c}\mathrm{Tm} \text { (ice) } \\
\left({ }^{\circ} \mathrm{C}\right)\end{array}$ & $\begin{array}{l}\text { Wt\% } \mathrm{NaCl} \\
\text { equivalent }\end{array}$ & $\begin{array}{l}\text { Th } \\
\left({ }^{\circ} \mathrm{C}\right)\end{array}$ \\
\hline \multicolumn{6}{|l|}{$137-504 \mathrm{~B}-$} \\
\hline 176R-1 (Piece 3) & 1569 & 6 & -1.9 to $-1.1(-1.56)$ & 3.2 to $1.9(2.67)$ & 127 to 144 (139) \\
\hline I8IR-2 (Piece 2) & 1621 & 9 & -3.1 to $-1.3(-2.00)$ & 5.1 to $2.2(3.37)$ & 141 to 163 (150) \\
\hline \multicolumn{6}{|l|}{$140-504 \mathrm{~B}-$} \\
\hline 186R-2 (Piece 7) & 1631 & 6 & -2.9 to $-1.9(-1.53)$ & 4.8 to $3.2(3.84)$ & 125 to $148(141)$ \\
\hline 194R-1 (Piece 23) & 1689 & 19 & -4.9 to $-1.3(-2.16)$ & 7.7 to $2.2(3.61)$ & 124 to 163 (144) \\
\hline 200R-2 (Piece 17) & 1733 & 7 & -3.6 to $-0.1(-1.47)$ & 5.9 to $0.2(2.45)$ & 149 to 160 (156) \\
\hline 201R-1 (Piece 5) & 1745 & 11 & -4.3 to $-0.6(-2.01)$ & 6.9 to $1.1(3.37)$ & 142 to 177 (153) \\
\hline 205R-1 (Piece 24) & 1760 & 14 & -2.4 to $-0.3(-1.41)$ & 4.0 to $0.5(2.40)$ & 140 to 161 (148) \\
\hline 208R-3 (Piece 1) & 1788 & 15 & -2.9 to $-1.2(-2.11)$ & 4.8 to $2.1(3.55)$ & 145 to $170(154)$ \\
\hline 210R-1 (Piece 10) & 1796 & 12 & -2.9 to $-0.6(-1.43)$ & 4.8 to $1.1(2.44)$ & 139 to 202 (160) \\
\hline $216 \mathrm{R}-1$ (Piece 8 ) & 1831 & 7 & -2.9 to $-1.7(-2.23)$ & 4.8 to $2.9(3.75)$ & 144 to 164 (151) \\
\hline 216R-I (Piece 13) & 1834 & 17 & -2.4 to $-1.7(-2.10)$ & 4.0 to $2.9(3.53)$ & 140 to $160(146)$ \\
\hline 22 IR-I (Piece 8 ) & 1878 & 10 & -2.2 to $-1.6(-1.91)$ & 3.7 to $2.7(3.23)$ & 133 to 152 (146) \\
\hline 228R-1 (Piece 13) & 1941 & iI & -3.1 to $-0.3(-2.05)$ & 5.1 to $0.5(3.43)$ & 144 to $181(162)$ \\
\hline 237R-1, (Piece 7) & 1992 & 17 & -2.4 to $-0.8(-1.88)$ & 4.0 to $1.4(3.18)$ & 143 to 175 (157) \\
\hline \multicolumn{6}{|l|}{ 148-504B- } \\
\hline 24IR-1 (Piece 15) & 2017 & 24 & -2.6 to $-0.6(-1.65)$ & 4.3 to $1.1(2.81)$ & 150 to 211 (167) \\
\hline 246R-1 (Piece 7) & 2052 & 17 & -2.2 to $-0.3(-1.68)$ & 3.7 to $0.5(2.86)$ & 151 to 177 (162) \\
\hline 247R-I (Piece 10) & 2057 & 37 & -2.3 to $-0.2(-1.13)$ & 3.9 to $0.4(1.94)$ & 151 to 203 (161) \\
\hline 248R-1 (Piece 7B) & 2062 & 25 & -2.1 to $-0.4(-1.04)$ & 3.5 to $0.7(1.79)$ & 154 to 191 (163) \\
\hline 249R-1 (Piece 15) & 2072 & 16 & -2.3 to $-0.7(-1.73)$ & 3.9 to $1.2(2.93)$ & 157 to 181 (166) \\
\hline 249R-1 (Piece 40) & 2073 & 17 & -2.5 to $-0.8(-1.91)$ & 4.2 to $1.4(3.24)$ & 152 to $196(167)$ \\
\hline 250R-1 (Piece 27) & 2081 & 25 & -2.1 to $-0.4(-1.58)$ & 3.5 to $0.7(2.70)$ & 152 to 202 (168) \\
\hline 25IR-I (Piece 5) & 2090 & 17 & -2.3 to $-0.6(-1.62)$ & 3.9 to $1.1(2.77)$ & 155 to 170 (158) \\
\hline
\end{tabular}

Notes: In some inclusions, either Tm(ice) and Th could not be measured. For $\mathrm{Tm}$ (ice), Th, and weight percentage $\mathrm{NaCl}$ equivalent, the range is given, followed by average in parentheses.

thermal vents at mid-ocean-ridge spreading centers, where the salinities of fluids vary between about 0.4 and $7 \mathrm{wt} \% \mathrm{NaCl}$ equivalent (from $70 \%$ below to $200 \%$ above seawater concentration) (Von Damm and Bischoff, 1987; Von Damm, 1988; Bowers et al., 1988; Butterfield et al., 1990) (see Fig. 3). The salinity variation of diabasehosted fluid inclusions, centered on that of seawater, may reflect slight modifications of seawater as it circulates at depth (see Kelley et al., 1995, for a discussion of possible controls on salinity variation).

Two samples from Leg 148 contain numerous secondary inclusions in healed planes that display quite low salinities (mostly between 0.2 and $1.5 \mathrm{wt} \% \mathrm{NaCl}$ equivalent). The reason that these secondary inclusions are uniformly less saline than others is unknown, however, their occurrence suggests that later fluids were less saline than earlier ones.

\section{Thermal Evolution}

At oceanic spreading centers seawater circulates between the seafloor and the subsurface magma chamber, spanning a pressure range of 200 to 750 bars with corresponding maximum temperatures of $300^{\circ}$ to $500^{\circ} \mathrm{C}$ (Bischoff and Rosenbauer, 1985). A predicted temperature range for greenschist-facies alteration in a subseafloor hydrothermal system is $250^{\circ}$ to $450^{\circ} \mathrm{C}$ (Mottl, 1983). The maximum fluid temperatures observed in many active East Pacific Rise hydrothermal vents are within a few degrees of $350^{\circ} \mathrm{C}$ (Von Damm et al., 1985). Oxygen isotope data on whole rocks and isolated secondary minerals from Leg 111 hydrothermally altered sheeted dikes indicate temperatures during metamorphism of $250^{\circ}-350^{\circ} \mathrm{C}$ (Alt et al., 1989). The greenschist alteration and vein-filling minerals in Hole 504B are thought to reflect initial penetration of seawater into the dike complex at temperatures of up to $350^{\circ} \mathrm{C}$ during hydrothermal circulation at the ridge axis (Becker et al., 1989; Shipboard Scientific Party, 1992).

Axial hydrothermal activity probably resulted in a cool crustal section after the axial heat source waned. Subsequently, sedimentation on the drifting ocean crust confined off-axis fluid circulation, and the upper crust of Hole 504B began to warm to its present temperature (Alt et al., 1986). The present-day borehole temperature increases with a linear gradient of $67^{\circ} \mathrm{C} / \mathrm{km}$ in the deep hole (see Fig. 8), from $149^{\circ} \mathrm{C}$ at a depth of $1298 \mathrm{mbsf}$ (Gable et al., 1989), to $165^{\circ} \mathrm{C}$

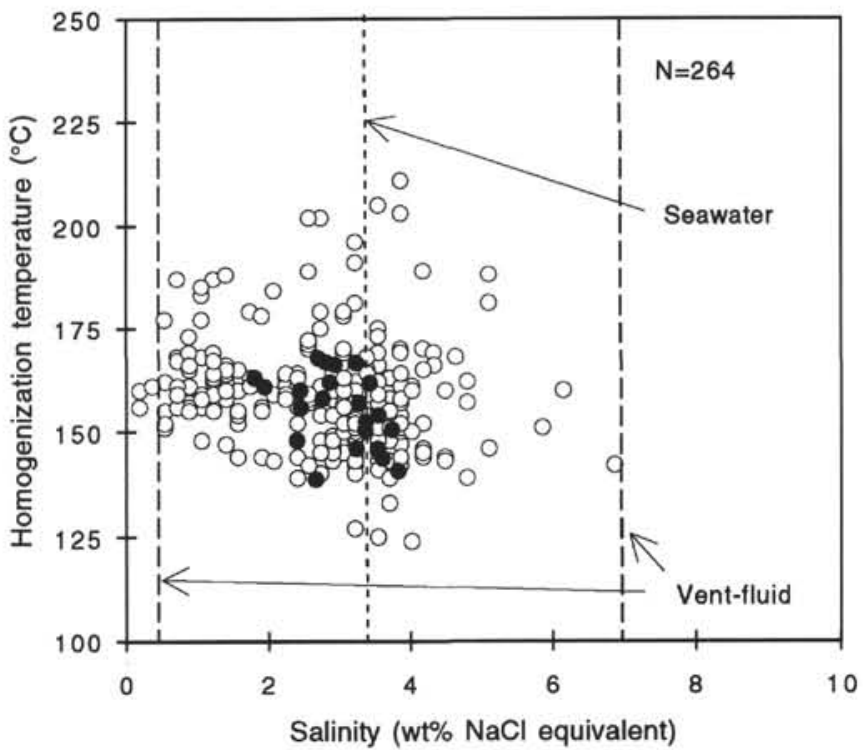

Figure 3. Fluid salinities and uncorrected homogenization temperatures for diabase-hosted inclusions. Primary(?) and secondary inclusions contain 0.2 to $7.7 \mathrm{wt} \% \mathrm{NaCl}$ equivalent and homogenize in the liquid phase at temperatures of $127^{\circ}$ to $211^{\circ} \mathrm{C}$. Open circles refer to the values of individual fluid inclusions; solid circles refer to the mean value of each sample.

at $1562 \mathrm{mbsf}$ (Becker et al., 1989), and then to $195^{\circ} \mathrm{C}$ at $2000 \mathrm{mbsf}$ (Shipboard Scientific Party, 1992).

The mean homogenization temperature of fluid inclusions from the sheeted dike section recovered during Legs $111,137,140$, and 148 increases systematically with depth (Figs. 7, 8), from about $140^{\circ} \mathrm{C}$ at $1370 \mathrm{mbsf}$ to about $170^{\circ} \mathrm{C}$ at $2100 \mathrm{mbsf}$. The values are in the stability range of albite but not congruent with the temperatures assumed for the formation of calcic plagioclase, which generally hosts the fluid inclusions. Instead, corrected homogenization temperatures from the plagioclase-hosted inclusions are close to the presentday borehole temperature (see Fig. 8). 


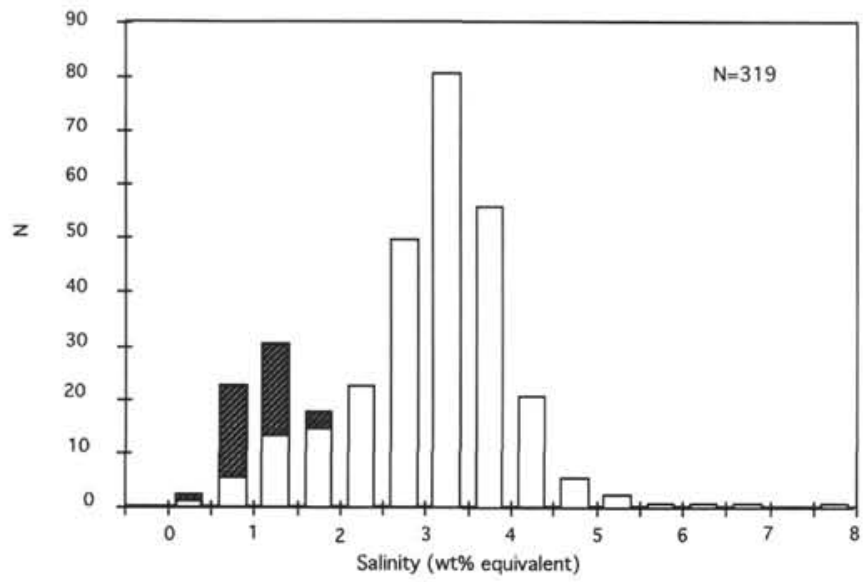

Figure 4. Histogram of the salinity of the fluid inclusions. The hatched bars represent fluid inclusions in secondary planes from Samples 148-504B247R-1 (Piece 10, 36-43 cm) and 148-504B-248R-1 (Piece 7B, 21-24 cm). The salinities of the fluid inclusions are centered on that of seawater $(3.2$ wt $\% \mathrm{NaCl}$ equivalent), and the secondary inclusions are of relatively lower salinities.

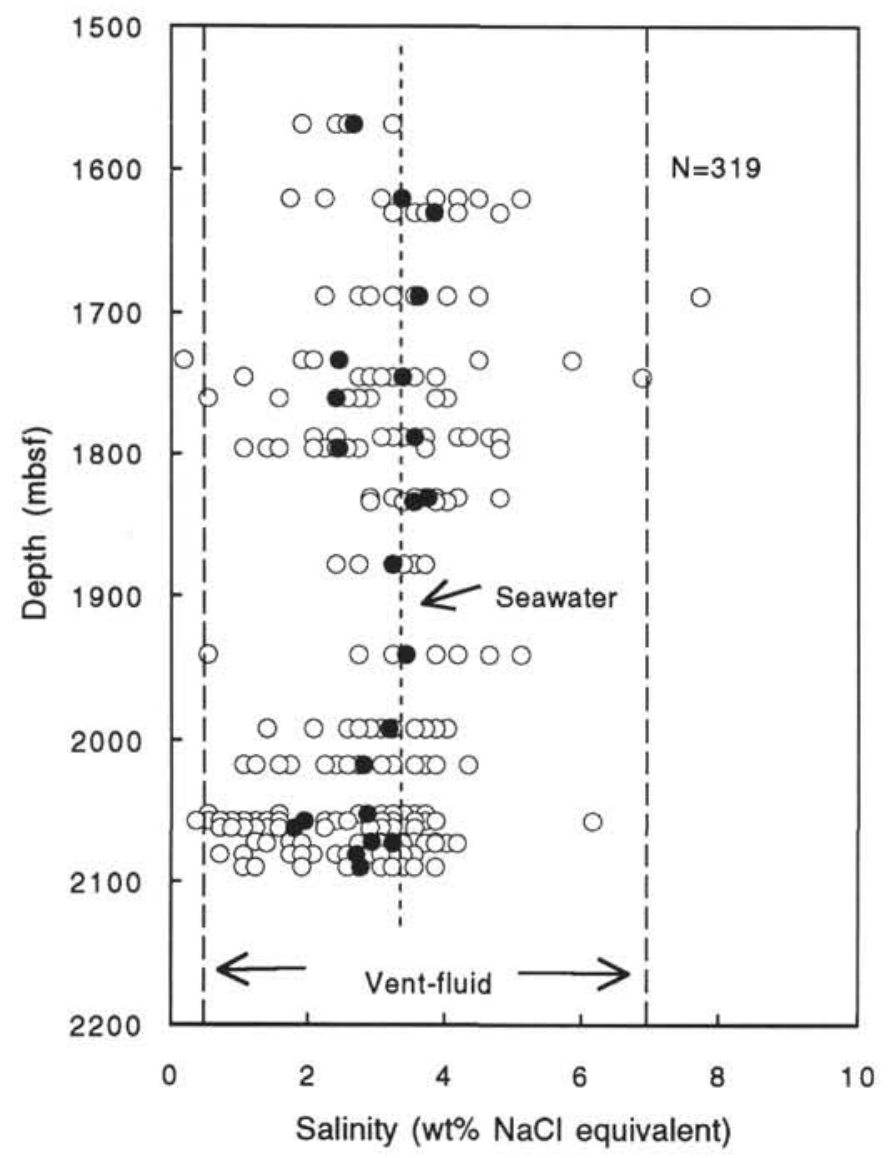

Figure 5. Graph of the salinity of fluid inclusions vs. depth of sample recovery, showing no significant change in salinity with depth. Open circles refer to the values of individual fluid inclusions; solid circles refer to the mean value of each sample.

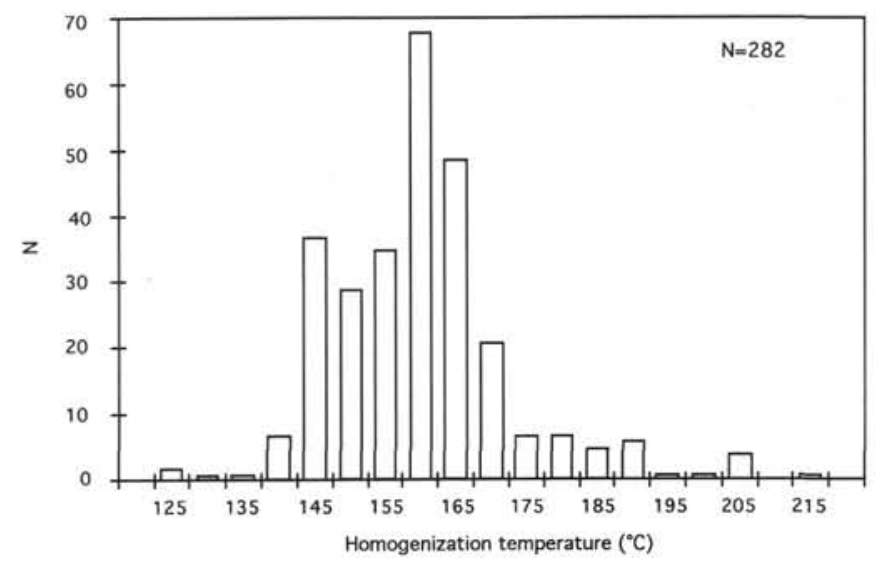

Figure 6. Histogram of the uncorrected homogenization temperature of the fluid inclusions. Most inclusions homogenized at temperatures from $140^{\circ}$ to $170^{\circ} \mathrm{C}$.

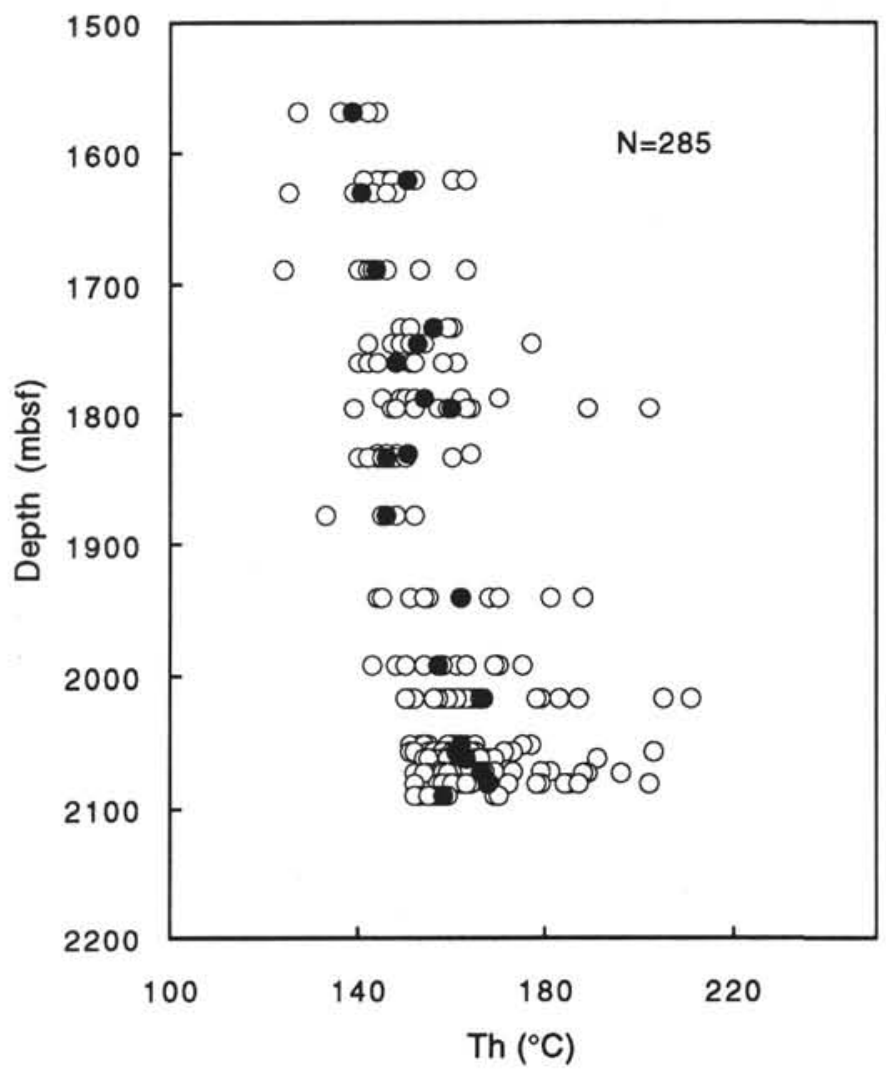

Figure 7. Graph of the homogenization temperature of the fluid inclusions vs. depth of sample recovery during Legs 137, 140, and 148, showing the change in homogenization temperature with depth. Open circles refer to the values of individual fluid inclusions; solid circles refer to the average of each sample.

"Trapping temperatures," calculated assuming a gas-free hydrostatic trapping condition, exhibit a gradient of about $60^{\circ} \mathrm{C} / \mathrm{km}$, which corresponds closely with the present borehole temperature gradient of $67^{\circ} \mathrm{C} / \mathrm{km}$ (Fig. 8). Calculated trapping temperatures assuming a gas-free lithostatic gradient are $15^{\circ}-25^{\circ} \mathrm{C}$ higher than those of the present borehole with a gradient of about $70^{\circ} \mathrm{C} / \mathrm{km}(\mathrm{Fig}$. 


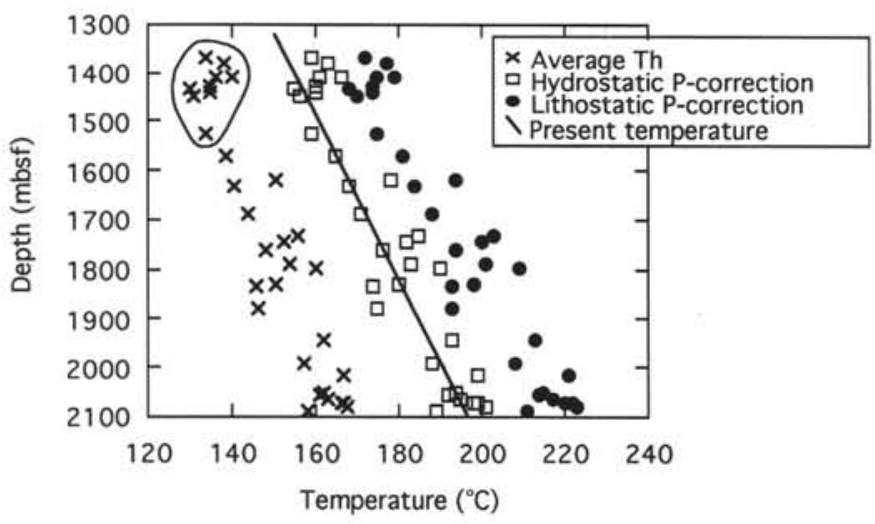

Figure 8. Graph of the average homogenization temperatures (uncorrected and corrected) of fluid inclusions vs. depth of sample recovery during Legs 111, 137, 140, and 148. Circled values are from Nehlig (1991). The hydrostat-corrected trapping temperatures increase with depth with a slope of about $60^{\circ} \mathrm{C} / \mathrm{km}$ (assuming a gas-free condition), which is consistent with the present borehole temperature gradient $67^{\circ} \mathrm{C} / \mathrm{km}$; the lithostat-corrected trapping temperatures increase with depth with a slope of about $70^{\circ} \mathrm{C} / \mathrm{km}$ (assuming a gas-free condition), with temperatures $15^{\circ}-25^{\circ} \mathrm{C}$ higher than those of the present borehole. If there is a small amount of gas present, resulting in steeper isochores in pressure-temperature space, then it is most likely that the lithostat-corrected trapping temperatures correspond to the presentday borehole temperatures.

8). However, these calculations are affected by the presence of a small amount of compressible gas (as determined by crushing experiments). Hanor (1980) discussed the behavior of fluid inclusions containing methane and concluded that neglecting the presence of gas results in an erroneously high estimate for entrapment temperature. If there is a small mount of gas (such as $\mathrm{CH}_{4}$ or $\mathrm{CO}_{2}$ ) present, therefore, the hydrostat-corrected trapping temperatures will be lower than present-day borehole temperatures and the lithostat-corrected trapping temperatures are most likely close to the present-day borehole temperatures.

No evidence exists on the original pressure regime during hydrothermal alteration of the lower sheeted dikes of Hole 504B. Fluids responsible for the formation of vein halos may have been at hydrostatic pressure, although this would require that an open fracture system existed continuously all the way to the overlying seafloor. At the other extreme, veins and vein halos might owe their existence to fluid-filled disk-shaped fractures under lithostatic pressure. Regardless of the precise pressure, all of the possible calculated trapping temperatures are lower than those of inclusions in quartz from Leg 111 quartz-sulfide veins (trapping temperatures of $270^{\circ}-$ $400^{\circ} \mathrm{C}$ ); the latter are thought to reflect on-axis and near-axis hydrothermal regimes (Schöps and Herzig, 1990).

The paradoxically low homogenization and trapping temperatures of the present inclusions lead to the following hypothesis. The fluid inclusions in hydrothermal plagioclase have behaved as open systems that continually reequilibrate with the ambient conditions. If formed initially at high temperature (perhaps $350^{\circ}-400^{\circ} \mathrm{C}$ ), then the inclusions have been underpressured ever since the mid-ocean-ridge heat source waned (Fig. 9). Furthermore, similar to the upper crust (Alt et al., 1986), the lower sheeted dikes may have subsequently reheated to their present temperature after the seafloor was sealed by Asedimentation and a new thermal regime was established (Fig. 9). This latter heating is purely speculative, however, as no firm mineralogical evidence shows that the deep sheeted dikes were ever cooler than they are now.

Plagioclase-hosted inclusions are more likely to act as open systems during conditions of underpressure than inclusions in quartz or

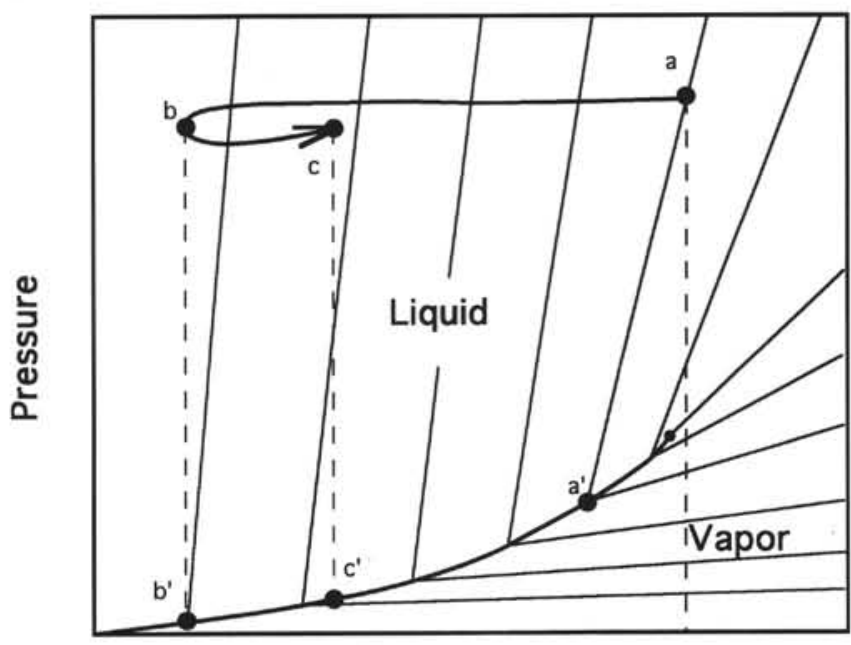

\section{Temperature}

Figure 9. Schematic diagram of the $\mathrm{NaCl}-\mathrm{H}_{2} \mathrm{O}$ system showing the generalized hypothetical path of plagioclase-hosted fluid inclusions in the deep sheeted dikes. Inclusions were trapped at conditions of high temperature (point a). As the magmatic heat source waned and the crust drifted off-axis, cooling at supercritical pressures took place (to point b). Inclusions trapped at point a experienced an internal pressure that decreased along the original trapping isochore to $a^{\prime}$, then along the two-phase liquid-vapor curve. When ambient conditions reached point $b$, the inclusion was underpressured at point $b^{\prime}$. This condition promotes inclusion shrinkage (specific volume decrease to the isochore through point b). Subsequent heating of the inclusion to point $\mathrm{c}$ as the crust ages would result in inclusion overpressuring (from $b^{\prime}$ to $c^{\prime}$ ). Inclusions may leak or expand. The net result is that inclusions are generally open systems and fail to preserve information on the original trapping conditions.

other more common inclusion host minerals, because of the excellent cleavage of plagioclase combined with the dynamic nature of the ocean crust. Underpressured conditions promote inclusion shrinkage a (as opposed to the more commonly studied inclusion stretching). Such shrinkage, and the corresponding specific volume reduction and density increase, may be accommodated in plagioclase by slip along cleavage planes. Thus, as in Figure 9, the original trapping isochore $\left(a-a^{\prime}\right)$ is shifted to lower specific volume (higher density and lower homogenization temperature) as the inclusions become underpressured (b-b'). Their new Th is markedly lower than the original Th, and may approach that of the ambient temperature condition.

Few previous fluid inclusion studies have focused on inclusions hosted by plagioclase. One recent study, however, reported such inclusion data from oceanic rocks (Vanko and Stakes, 1991). A reexamination of those data reveals that many samples exhibit unusually low homogenization temperatures for plagioclase-hosted inclusions. An explanation similar to that hypothesized here for the Hole 504B inclusions is possibly also relevant to the Hole 735B samples (Vanko and Stakes, 1991).

In deep boreholes with core samples and where downhole temperature logging is problematic, fluid inclusion studies of inclusions hosted by weak minerals such as plagioclase (others may include fluorite, sulfates, and carbonates) may provide information on temperature conditions in the hole that are otherwise unavailable. Furthermore, if inclusions point to a linear thermal gradient, then this may be taken as evidence that fluid circulation has essentially ceased. This is because one effect of active fluid circulation is to create a nonlinear gradient, concave-downward if warm fluid is ascending, and concaveupward if cool fluid is descending. 


\section{CONCLUSIONS}

Fluid inclusions are abundant in plagioclase, particularly within highly altered vein halos, as isolated individuals or along the healed planes of secondary inclusions. All inclusions are two phase (liquid plus vapor) and liquid dominated, with typical diameters ranging from a few to several tens of microns and varying from angular to irregular in shape.

Inclusion fluids represent modified seawater. The ice-melting temperatures range from $-0.1^{\circ}$ to $-4.9^{\circ} \mathrm{C}$, and the corresponding salinities range from 0.2 to $7.7 \mathrm{wt} \% \mathrm{NaCl}$ equivalent. Average salinities are centered on that of seawater ( $3.2 \mathrm{wt} \% \mathrm{NaCl}$ equivalent), with the range from $60 \%$ below to $240 \%$ above that of seawater, similar to the range of salinities of modern active vent fluids. Secondary inclusions within some healed planes contain lower salinities $(0.2-1.5 \mathrm{wt} \%$ $\mathrm{NaCl}$ equivalent).

The measured (uncorrected) homogenization temperatures display a range of $140^{\circ}-170^{\circ} \mathrm{C}$, which is lower than that suggested by the formation of calcic plagioclase (plus hornblende), which generally hosts the fluid inclusions $\left(\geq 400^{\circ} \mathrm{C}\right)$.

Gas-free, hydrostat-corrected trapping temperatures range from $165^{\circ}$ at $1730 \mathrm{mbsf}$ to $205^{\circ} \mathrm{C}$ at $2100 \mathrm{mbsf}$, consistent with the borehole temperatures (from $160^{\circ} \mathrm{C}$ at $1500 \mathrm{mbsf}$ to $195^{\circ} \mathrm{C}$ at $2100 \mathrm{mbsf}$ ). The gas-free, lithostat-corrected trapping temperatures range from 180 to $223^{\circ} \mathrm{C}$, which are $15^{\circ}-25^{\circ} \mathrm{C}$ higher than temperatures in the borehole. However, if there is a small amount of compressible gas present (as crushing experiments demonstrate), resulting in steeper isochores in pressure-temperature space, then the lithostat-corrected trapping temperatures most likely correspond to the borehole temperatures.

The sheeted dike complex at Hole 504B was altered at the ridge axis $5.9 \mathrm{~m} . \mathrm{y}$. ago at high temperature $\left(\geq 400^{\circ} \mathrm{C}\right)$. The diabase-hosted fluid inclusions, however, record the temperatures appropriate for the present-day conditions. Thus, the fluid inclusions in hydrothermal plagioclase have behaved as open systems that continually reequilibrate with the ambient pressure and temperature conditions, and must be interpreted in terms of the history of temperature and pressure changes undergone by the young ocean crust, which formed at the mid-ocean-ridge axis and was then transported away from the rift environment.

\section{ACKNOWLEDGMENTS}

This study was supported by JOI/USSAC and the NSF (OCE 9114832). Thoughtful reviews were provided by Jeff Alt, Dave Crow, and an anonymous reviewer.

\section{REFERENCES}

Alexander, R.J., and Harper, G.D., 1992. The Josephine ophiolite: an ancient analogue for slow- to intermediate-spreading oceanic ridges. In Parson, L.M., Murton, B.J., and Browning, P. (Eds.), Ophiolites and Their Modern Oceanic Analogues, Geol. Soc. Spec. Publ. London, 60:3-38.

Alt, J.C., Anderson, T.F., Bonnell, L., and Muehlenbachs, K., 1989. Mineralogy, chemistry, and stable isotopic compositions of hydrothermally altered sheeted dikes: ODP Hole 504B, Leg 111. In Becker, K., Sakai, H., et al., Proc. ODP, Sci. Results, 111: College Station, TX (Ocean Drilling Program), 27-40.

Alt, J.C., Honnorez, J., Laverne, C., and Emmermann, R., 1986. Hydrothermal alteration of a I km section through the upper oceanic crust, Deep Sea Drilling Project Hole 504B: mineralogy, chemistry, and evolution of seawater-basalt interactions. J. Geophys. Res., 91:10309-10335.

Alt, J.C., Laverne, C., and Muehlenbachs, K., 1985. Alteration of the upper oceanic crust: mineralogy and processes in Deep Sea Drilling Project Hole 504B, Leg 83. In Anderson, R.N., Honnorez, J., Becker, K., et al.,
Init. Repts. DSDP, 83: Washington (U.S. Govt. Printing Office), 217247.

Becker, K., Sakai, H., Adamson, A.C., Alexandrovich, J., Alt, J.C., Anderson, R.N., Bideau, D., Gable, R., Herzig, P.M., Houghton, S.D., Ishizuka, H., Kawahata, H., Kinoshita, H., Langseth, M.G., Lovell, M.A., Malpas, J., Masuda, H., Merrill, R.B., Morin, R.H., Mottl, M.J., Pariso, J.E., Pezard, P.A., Phillips, J.D., Sparks, J.W., and Uhlig, S., 1989. Drilling deep into young oceanic crust, Hole 504B, Costa Rica Rift. Rev. Geophys., 27:79-102.

Bischoff, J.L., and Rosenbauer, R.J., 1985. An empirical equation of state for hydrothermal seawater (3.2 percent $\mathrm{NaCl}$ ). Am. J. Sci., 285:725-763.

Bodnar, R.J., 1993. Revised equation and table for determining the freezing point depression of $\mathrm{H}_{2} \mathrm{O}-\mathrm{NaCl}$ solutions. Geochim. Cosmochim. Acta, 57:683-684.

Bowers, T.S., Campbell, A.C., Measures, C.I., Spivack, A.J., Khadem, M., and Edmond, J.M.. 1988. Chemical controls on the composition of vent fluids at $13^{\circ} \mathrm{N}-11^{\circ} \mathrm{N}$ and $21^{\circ} \mathrm{N}$, East Pacific Rise. J. Geophys. Res., 93:4522-4536.

Butterfield, D.A., Massoth, G.J., McDuff, R.E., Lupton, J.E., and Lilley, M.D., 1990. Geochemistry of hydrothermal fluid from Axial Seamount Hydrothermal Emissions Study vent field, Juan de Fuca Ridge: subseafloor boiling and subsequent fluid-rock alteration. J. Geophys. Res., 95:12895-12921.

Gable, R., Morin, R.H., and Becker, K., 1989. Geothermal state of Hole 504B: ODP Leg 111 overview. In Becker, K., Sakai, H., et al., Proc. ODP. Sci. Results, 111: College Station, TX (Ocean Drilling Program), $87-96$.

Hanor, J.S., 1980. Dissolved methane in sedimentary brines: potential effect on the PVT properties of fluid inclusions. Econ. Geol., 57:603-617.

Harper, G.D., Bowman, J.R., and Kuhns, R., 1988. A field, chemical, and stable isotope study of subseafloor metamorphism of the Josephine ophiolite, California-Oregon. J. Geophys. Res., 93:4625-4656.

Hobart, M.A., Langseth, M.G., and Anderson, R.N., 1985. A geothermal and geophysical survey on the south flank of the Costa Rica Rift: Sites 504 and 505. In Anderson, R.N., Honnorez, J., Becker, K., et al., Init. Repts. DSDP, 83: Washington (U.S. Govt. Printing Office), 379-404.

Honnorez, J., Alt, J.C., Honnorez-Guerstein, B.-M., Laverne, C., Muehlenbachs, K., Ruiz, J., and Saltzman, E., 1985. Stockwork-like sulfide mineralization in young oceanic crust: Deep Sea Drilling Project Hole 504B. In Anderson, R.N., Honnorez, J., Becker, K., et al., Init. Repts. DSDP, 83: Washington (U.S. Govt. Printing Office), 263-282.

Kawahata, H., and Furuta, T., 1985. Sub-seafloor hydrothermal alteration in the Galapagos spreading center. Chem. Geol., 49:259-274.

Kawahata, H., Kusakabe, M., and Kikuchi, Y., 1987. Strontium, oxygen and hydrogen isotope geochemistry of hydrothermally altered and weathered rocks in DSDP Hole 504B, Costa Rica Rift. Earth Planet. Sci. Lett., 85:343-355.

Kelley, D.S., Gillis, K.M., and Thompson, G., 1993. Fluid evolution in submarine magma-hydrothermal systems at the Mid-Atlantic Ridge. J. Geophys. Res., 98:19579-19596.

Kelley, D.S., and Robinson, P.T., 1990. Development of a brine-dominated hydrothermal system at temperatures of $400-500^{\circ} \mathrm{C}$ in the upper level plutonic sequence, Troodos ophiolite, Cyprus. Geochim. Cosmochim. Acta, 54:653-661.

Kelley, D.S., Robinson, P.T., and Malpas, J.G., 1992. Processes of brine generation and circulation in the oceanic crust: fluid inclusion evidence from the Troodos ophiolite, Cyprus. J. Geophys. Res., 97:9307-9322.

Kelley, D.S., Vanko, D.A., and Gu, C., 1995. Fluid evolution in oceanic crustal layer 2: fluid inclusion evidence from the sheeted dike complex, Hole 504B, Costa Rica Rift. In Erzinger, J., Becker, K., Dick, H.J.B., and Stokking, L.B. (Eds.), Proc. ODP, Sci. Results, 137/140: College Station, TX (Ocean Drilling Program), 191-205.

Laverne, C., Vanko, D.A., Tartarotti, P., and Alt, J.C., 1995. Chemistry and geothermometry of secondary minerals from the deep sheeted dike complex, Hole 504B. In Erzinger, J., Becker, K., Dick, H.J.B., and Stokking, L.B. (Eds.), Proc. ODP, Sci. Results, 137/140: College Station, TX (Ocean Drilling Program), 167-189.

Mottl, M.J., 1983. Metabasalts, axial hot springs, and the structure of hydrothermal systems at mid-ocean ridges. Geol. Soc. Am. Bull., 94:161-180.

Nehlig, P., 1991. Salinity of oceanic hydrothermal fluids: a fluid inclusion study. Earth Planet. Sci. Lett., 102:310-325.

Nehlig, P., and Juteau, T., 1988. Flow porosities, permeabilities and preliminary data on fluid inclusions and fossil thermal gradients in the crustal sequence of the Semail ophiolite (Oman). Tectonophysics, 151:199-221. 
Pflumio, C., 1991. Evidences for polyphased oceanic alteration of the extrusive sequence of the Semail ophiolite from the Salahi Block (Northern Oman). In Peters, Tj., Nicolas, A., and Coleman, R.G. (Eds.), Ophiolite Genesis and Evolution of the Oceanic Lithosphere: Dordrecht (Kluwer Acad. Publ.), 3।3-35!.

Regba, M.. Agrinier, P., Pflumio, C., and Loubet, M., 1991. A geochemical study of a fossil oceanic hydrothermal discharge zone in the Oman ophiolite (Zuha sulphide prospect): evidence for a polyphased hydrothermal history. In Peters, Tj., Nicolas, A., and Coleman, R.G. (Eds.), Ophiolite Genesis and Evolution of the Oceanic Lithosphere: Dordrecht (Kluwer Acad. Publ.), 353-383.

Richardson, C.J., Cann, J.R., Richards, H.G., and Cowan, J.G., 1987. Metaldepleted root zones of the Troodos ore-forming hydrothermal systems, Cyprus. Earth Planet. Sci. Lett., 84:243-253.

Roedder, E., 1970. Application of an improved crushing microscope stage to studies of the gases in fluid inclusions. Schweiz. Mineral. Petrogr. Mitt., 50:41-58.

1984. Fluid inclusions. Rev. Mineral., Mineral. Soc. Am., 12.

Schöps, D., and Herzig, P.M., 1990. Sulfide composition and microthermometry of fluid inclusions in the Leg 111 sheeted dike section of Ocean Drilling Program Hole 504B, Costa Rica Rift. J. Geophys. Res., 95: 8405-8418.

Seyfried, W.E., Jr., Ding, K., and Berndt, M.E., 1991. Phase equilibria constraints on the chemistry of hot spring fluids at mid-ocean ridges. Geochim. Cosmochim. Acta, 55:3559-3580.

Shipboard Scientific Party, 1992. Site 504. In Dick, H.J.B., Erzinger, J., Stokking, L.B., et al., Proc. ODP. Init. Repts., 140: College Station, TX (Ocean Drilling Program), 37-200.

, 1993. Site 504. In Alt, J.C., Kinoshita, H., Stokking, L.B., et al. Proc. ODP, Init. Repts., 148: College Station, TX (Ocean Drilling Program), 27-121.
Stakes, D.S., and Vanko, D.A., 1986. Multistage hydrothermal alteration of gabbroic rocks from the failed Mathematician Ridge. Earth Planet. Sci. Lett., 79:75-92.

Vanko, D.A., 1988. Temperature, pressure and composition of hydrothermal fluids, with their bearing on the magnitude of tectonic uplift at mid-ocean ridges, inferred from fluid inclusions in oceanic layer 3 rocks. J. Geophys. Res., 93:4595-4611.

Vanko, D.A., and Stakes, D.S., 1991. Fluids in oceanic layer 3: evidence from veined rocks, Hole 735B, Southwest Indian Ridge. In Von Herzen, R.P., Robinson, P.T., et al., Proc. ODP, Sci. Results, 118: College Station, TX (Ocean Drilling Program), 181-215.

Von Damm, K.L., 1988. Systematic and postulated controls on submarine hydrothermal solution chemistry. J. Geophys. Res., 39:4551-4561.

Von Damm, K.L., and Bischoff, J.L., 1987. Chemistry of hydrothermal solutions from the southern Juan de Fuca Ridge. I. Geophys. Res., 92:11334 11346.

Von Damm, K.L., Edmond, J.M., Grant, B., Measures, C.I., Walden, B., and Weiss, R.F., 1985. Chemistry of submarine hydrothermal solutions at $21^{\circ}$ N, East Pacific Rise. Geochim. Cosmochim. Acta, 49:2197-2220.

Zhang, Y.-G., and Frantz, J.D., 1987. Determination of the homogenization temperatures and densities of supercritical fluids in the system $\mathrm{NaCl}$ $\mathrm{KCl}-\mathrm{CaCl}_{2}-\mathrm{H}_{2} \mathrm{O}$ using synthetic fluid inclusions. Chem.Geol., 64:335350 .

Date of initial receipt: 17 August 1994

Date of acceptance: 26 January 1995

Ms 148SR-125 